\title{
PROTOTIPE E-KLINIK UNTUK LAYANAN KESEHATAN BERBASIS WEB PADA BALAI PENGOBATAN KANTOR PUSAT KEMENTERIAN PERTANIAN
}

\author{
Tri Pujadi \\ Jurusan Sistem Informasi, Fakultas Ilmu Komputer, Universitas Bina Nusantara \\ Jln. K.H. Syahdan No. 9, Palmerah, Jakarta Barat 11480 \\ Tripujadi@binus.ac.id
}

\begin{abstract}
This report discusses about the administration service at House of Medicinal Treatment in Central Office of The Ministry of Agriculture Republic of Indonesia. The administration service build in a web-based system, which has changed the administration system from manual to computerized. This system, which is known as Clinic Information System, facilitate the employee at House of Medicinal Treatment when they do their medical service in clinic from patient registration, medical record and report. The conclusion of this report is that the employees in the house of medicinal treatment is assisted enough with the design of this web-based system, but the function and the accuracy of the system should still be improved.
\end{abstract}

Keywords: administration, web-based application system

\begin{abstract}
ABSTRAK
Laporan ini berisi mengenai pelayanan administrasi pada Balai Pengobatan di Kantor Pusat Kementerian Pertanian Republik Indonesia. Prosedur pelayanan administrasi tersebut dibuat dalam bentuk sistem yang berbasis web sehingga mengubah sistem administrasi yang sebelumnya manual menjadi terkomputerisasi. Metodologi menggunakan metode daur hidup pengembangan sistem yang terdiri dari inisisasi, analisis, desain dan implementasi. Sistem yang dikenal dengan sebutan Sistem Informasi Klinik ini memudahkan pegawai balai pengobatan dalam melakukan rangkaian proses pelayanan di klinik dari pendaftaran pasien, input riwayat penyakit hingga laporan. Kesimpulan dari laporan ini adalah, para pegawai balai pengobatan cukup terbantu dengan dirancangnya sistem yang berbasis web ini, hanya perlu ditingkatkan lagi fungsi dan akurasi pada sistem yang telah berjalan.
\end{abstract}

Kata kunci: administrasi, sistem aplikasi berbasis web 


\section{PENDAHULUAN}

Kementerian Pertanian yang membidangi sektor pertanian, beralamat di Jalan Harsono RM No. 3 Ragunan, Jakarta Selatan. Kementerian ini mempunyai peran sebagai penyedia pangan bagi penduduk Indonesia, penopang pertumbuhan sektor industri, penghasil devisa hasil bahan ekspor dan pasar yang besar bagi sektor ekonomi lainnya.

Sebagai perwujudan visi birokrasi yang sehat, berintegritas dan dinamis, Biro Organisasi dan Kepegawaian mempunyai tugas melaksanakan pembinaan dan penyempurnaan organisasi dan ketatalaksanaan, perencanaan dan pengembangan pegawai serta mutasi pegawai. Dalam pelaksanaan pembinaan kepegawaian, administrasi layanan pengobatan berada di bawah tanggung jawabnya. Agar tersedia layanan yang baik kepada pengguna balai pengobatan, dipandang perlunya mengembangkan software aplikasi administrasi layanan pengobatan berbasis Web. Seperti umumnya balai pengobatan instansi, maka unit ini memberikan layanan untuk para pegawai beserta tanggungannya sehingga selain pegawai dan tanggungannya tidak diperkenankan berobat di Balai Pengobatan ini.

Menurut Whitten (2007) dan O’Brien (2008), aplikasi Sistem Berbasis Web adalah pemakaian sumberdaya TI yang terintegrasi dalam mengolah dan menyediakan informasi dengan memanfaatkan jaringan global di situs internet yang saling terhubung sehingga data yang telah diolah dapat diakses oleh siapapun yang terhubung ke jaringan tersebut. Sedangkan pengertian pelayanan (Budiono: 2005), adalah suatu cara melayani, berasal dari kata layan, melayani yang artinya membantu, menyiapkan atau mengurus apa-apa yang diperlukan seseorang. Dan administrasi, masih menurut Budiono adalah usaha dan kegiatan yang meliputi penetapan tujuan serta penetapan cara-cara penyelenggaraan pemerintahan kegiatan kantor dan tata-usaha.

Dengan demikian, software aplikasi administrasi layanan pengobatan berbasis web yang dimaksudkan tersebut, adalah penyediaan sumber daya TI yang terintegrasi dan berbasis Web, yang mengolah dan menyediakan informasi untuk melayanai seseorang, yaitu pasien dengan cara-cara penyelenggaraan administrasi yang baik.

\section{METODE PENELITIAN}

Metode pengembangan software yang baik, menggunakan tahapan pengembangan Sistem Informasi. Metode ini menurut Whitten (2007) terdiri dari inisisasi, analisis, desain dan implementasi sistem. Dalam melakukan langkah inisiasi dan analisis, diperlukan pemahaman prosedur yang berhubungan dengan objek yang akan dikembangkan sistemnya dan prosedur adalah rangkaian tahapan demi tahapan dari instruksi dan logika yang digunakan untuk menyelesaikan suatu proses bisnis. Sedangkan desain sistem mencakup desain database, navigasi, tampilan dan dan rancangan keluarannya. Untuk implementasinya, menggunakan bantuan tool dalam membuat program e-klinik ini, yaitu perangkat lunak PHP dan MySql.

PHP adalah bahasa pemrograman script yang paling banyak dipakai saat ini. PHP banyak dipakai untuk memrogram situs web dinamis, walaupun tidak tertutup kemungkinan digunakan untuk pemakaian lain. PHP dibuat oleh Rasmus Lerdorf dan Zend yang wujudnya berupa sekumpulan script yang digunakan untuk mengolah data form dari web. Selanjutnya Rasmus merilis kode sumber tersebut untuk umum dan menamakannya PHP/FI, kependekan dari Hypertext Preprocessing'/Form Interpreter. Dengan perilisan kode sumber ini menjadi open source, maka banyak programmer yang tertarik untuk ikut mengembangkan PHP. Sedangkan MySql, dipublikasikan Larson dan Axmark adalah Relational Database Management System (RDBMS) yang open source yang saat ini dimiliki oleh Sun Microsystems, Inc. 


\section{HASIL DAN PEMBAHASAN}

\section{Inisiasi dan Analisis Sistem}

Secara umum prosedur layanan pengobatan pada Kementerian Pertanian dibagi menjadi dua, yaitu layanan berobat ke dokter umum dan layanan berobat ke dokter gigi.

\section{Prosedur Layanan Berobat Ke Dokter Umum}

Proses berobat pada Gambar 1, dimulai ketika pasien mendatangi balai pengobatan. Pasien memberikan kartu berobat kepada petugas kartu. Petugas kartu akan mencocokkan NIP dan nomor kartu pasien, map riwayat penyakit pasien yang ada di Balai Pengobatan. Setelah ditemukan, petugas akan memberikan map riwayat penyakit yang berisi data rekam medik kepada pasien. Pasien kemudian menuju ke ruang diagnosa dokter dan menyerahkan data rekam medik kepada Dokter Umum. Dokter umum akan mengecek data rekam medik pasien sebelumnya dan mendiagnosa penyakit yang sedang diderita pasien saat itu. Dokter akan menentukan apakah pasien perlu melakukan tes pengecekan di laboratorium atau tidak. Jika tidak, maka dokter umum akan menentukan hasil diagnose penyakit. Jika perlu, maka pasien akan menuju laboratorium untuk melakukan tes laboratorium. Hasil tes laboratorium dari analis laboratorium dibawa kembali ke dokter umum yang akan memberikan hasil diagnosis kepada pasien. Pasien kemudian memberikan hasil diagnosis kepada perawat yang akan memberikan obat sesuai resep dokter perawat juga memberikan data obat dan hasil diagnosa kepada petugas kartu. Proses berobat diakhiri oleh petugas kartu yang akan mencatat rekam medik dan semua kunjungan pasien ke dalam map riwayat penyakit pasien

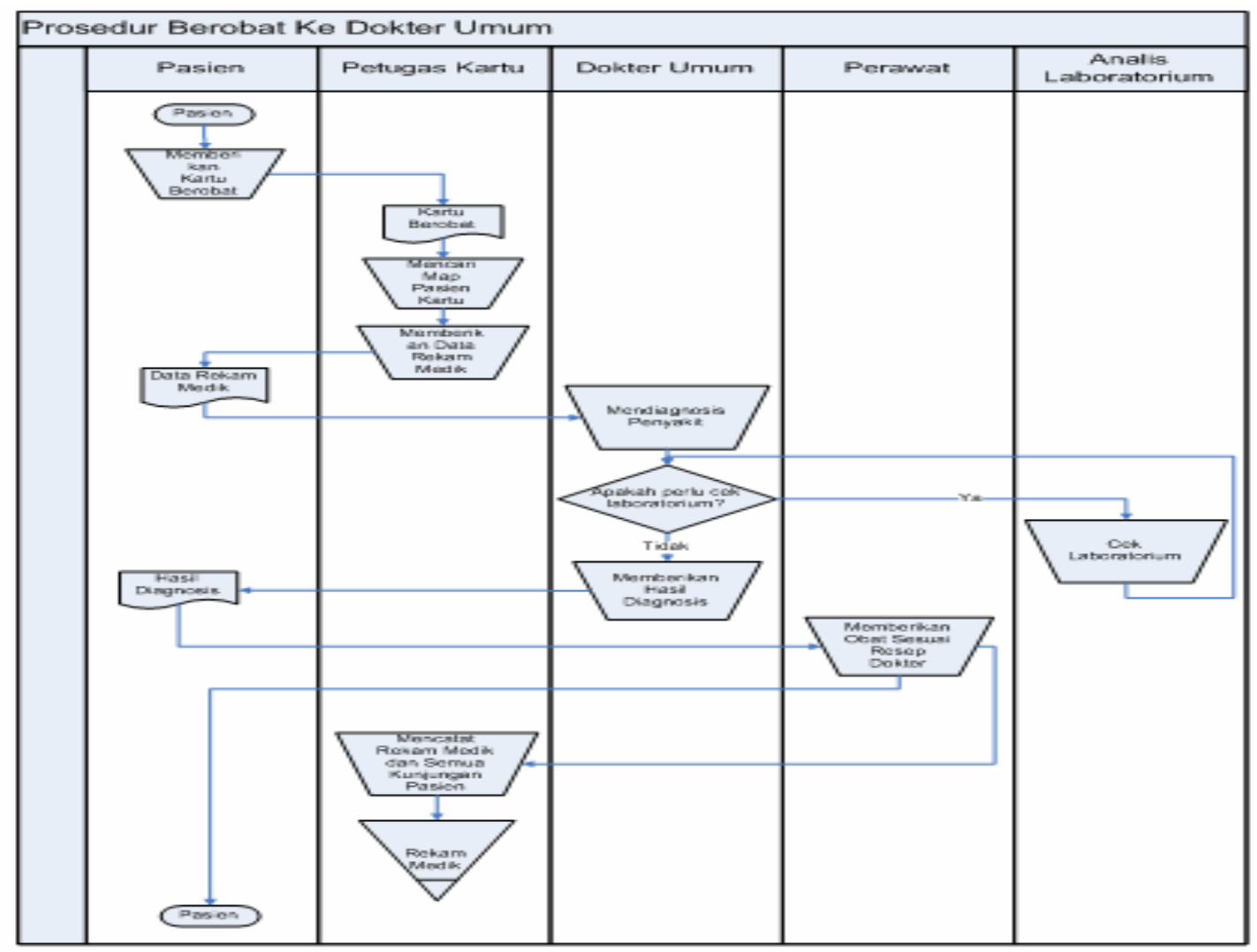

Gambar 1 Prosedur Berobat ke Dokter Umum 


\section{Prosedur Layanan Berobat Ke Dokter Gigi}

Layanan berobat ke dokter gigi menggunakan prosedur yang mirip seperti di atas. Proses berobat dimulai ketika pasien mendaftar untuk mendapatkan nomor urut periksa. Pasien juga memberikan kartu berobatnya ke petugas kartu. Petugas kemudian mencari data riwayat penyakit pasien yang ada di balai pengobatan dengan cara mencocokkan NIP dan No Kartu yang ada di kartu berobat pasien dengan map riwayat penyakit pasien yang ada di balai pengobatan. Setelah map riwayat penyakit pasien ditemukan, maka petugas kartu akan memberikan data rekam medik kepada pasien. Pasien akan menunggu sampai nomor urutnya dipanggil oleh perawat gigi. Perawat akan mencatat keluhan yang sedang dialami pasien ke rekam medik. Data tersebut kemudian diserahkan kepada dokter gigi dan petugas kartu. Dokter gigi kemudian memeriksa keadaan gigi pasien dan mengobatinya. Dokter gigi akan menentukan apakah pasien memerlukan resep obat untuk penyakit yang dideritanya. Jika tidak, maka dokter gigi akan langsung mencatat hasil periksa dokter. Selain itu, dokter akan memberikan resep obat ke bagian obat dan mencatat hasil periksa dokter. Bagian obat kemudian akan memberikan obat sesuai resep dokter kepada pasien. Proses berobat diakhiri oleh petugas kartu yang akan mencatat seluruh data kunjungan pasien ke map rekam medik.

\section{Analisis Permasalahan Menggunakan Fishbone Diagram}

Diagram Fishbone (Terninko, 2000), Kirschman (1998) dari Ishikawa adalah tool yang banyak digunakan di dunia dalam mengidentifikasi faktor penyebab problem/masalah. Diagram "tulang ikan" ini dikenal dengan cause and effect diagram, digambarkan dengan bagian kepala (sebagai effect) dan bagian tubuh ikan berupa rangka serta duri-durinya digambarkan sebagai penyebab (cause) suatu permasalahan yang timbul.

Dari gambar tersebut akan terlihat faktor penyebab problem yang (kemungkinan) terdiri dari : bahan, perangkat, manusia dan metode/cara. Semua yang berhubungan dengan obat, alat medis, petugas kesehatan, dan metode yang "saat ini" dituliskan dan dianalisa faktor mana yang terindikasi "menyimpang" dan berpotensi terjadi problem. Dan ketika sudah ditemukan satu atau beberapa "penyebab", dilakukan kajian lebih rinci untuk menemukan akar penyebab di dalamnya yang "tersembunyi”. Dengan menerapkan diagram Fishbone ini dapat menolong kita untuk menemukan akar "penyebab" terjadinya masalah. Apabila "masalah" dan "penyebab" sudah diketahui secara pasti, maka tindakan perbaikan mudah dilakukan. Dengan diagram ini, semuanya menjadi lebih jelas dan memungkinkan untuk dapat melihat semua "penyebab" dan mencari "akar" permasalahan sebenarnya. Hasil analisis dengan fishbone diagram pada administrasi layanan pengobatan pada Kementerian Pertanian dapat dilihat pada Gambar 2.

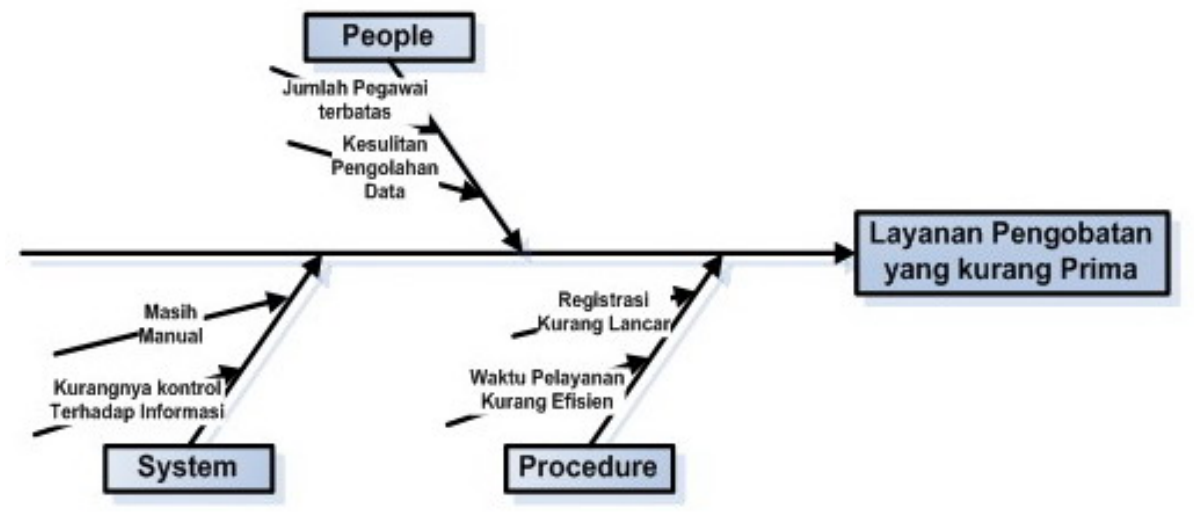

Gambar 2 Fishbone Diagram 
Gambar 2 menunjukkan penyebab mengapa layanan pengobatan di Balai Pengobatan kurang prima. Penyebabnya ada tiga kategori utama, yaitu people, procedure, dan sistem. Dari people memiliki masalah jumlah pegawai yang terbatas dan kesulitan pegawai dalam melakukan pengolahan data. Sistem yang ada pun masih manual dan masih kurang kontrol terhadap informasi. Adapun dari prosedur registrasi masih kurang lancar, dan waktu pelayanan masih kurang efisien.

\section{Kendala yang Dialami Balai Pengobatan Selama Melakukan Layanan}

Beberapa kendala klinik dalam melakukan layanan, di antaranya adalah: kurangnya kontrol terhadap informasi mengenai ketersediaan dan keluar masuknya obat di balai pengobatan tersebut; keterbatasan jumlah personil menyebabkan kesulitan menyediakan informasi atau laporan untuk mengetahui kegiatan klinik serta prosedur pendaftaran kurang lancar, misalnya ketika pasien datang tanpa membawa kartu berobatnya, maka dapat terjadi akan sulit menemukan riwayat penyakit pasien sehingga layanan menjadi lambat. Untuk mengatasinya, maka diusulkan membuat aplikasi berbasis web yang bernama e-Klinik.

Manfaat yang akan diperoleh dengan adanya sistem ini adalah: mempercepat dan menambah keakuratan data dalam proses layanan pengobatan, terutama ketika proses pendaftaran pasien; menambah kontrol terhadap informasi mengenai ketersediaan obat dan hal-hal lain dalam balai pengobatan serta memberikan informasi mengenai klinik seperti jadwal dokter, berita klinik dan lainnya yang dapat diakses langsung oleh pasien, kapan pun dan dimana pun pasien berada.

\section{Perancangan Sistem}

Pengembangan sistem informasi klinik ini menggunakan analisis sistem dengan pendekatan model. Beberapa model diagram yang digunakan sebagai alat bantu antara lain UML (Unified Modeling), DFD (Data Flow Diagram), ERD (Entity Relationship Diagram), dan Flowchart

\section{Sistem Context}

Gambar 3 merupakan Context Diagram yang menunjukkan aliran data yang terjadi antara Sistem Informasi Klinik dengan pihak-pihak yang terlibat langsung dengan sistem. Pasien melakukan input pendaftaran pasien dan mendapatkan urutan pendaftaran pasien dan jadwal dokter dari sistem. Sedangkan untuk keempat entitas lainnya, yaitu dokter, suster, kepala klinik, dan administrator memiliki hak akses masing-masing terhadap sistem sesuai dengan jabatannya masing-masing. Oleh karena itu, untuk membedakan hak akses masing-masing, keempat entitas ini harus memberikan username dan password kepada sistem. Dokter dapat memasukkan atau mengubah data rekam medis dan mendapatkan data rekam medis dari sistem. Sedangkan suster melakukan input terhadap data obat.dan input pendaftaran pasien. Suster juga mendapatkan informasi mengenai obat dan urutan pendaftaran pasien dari sistem. Kepala klinik mendapatkan informasi mengenai laporan pasien dan laporan obat dari sistem. Sedangkan administrator mendapatkan hak akses keseluruhan (termasuk mengubah kuota pendaftaran, jadwal praktek dokter, data pasien dan akun login pegawai klinik).

Selanjutnya dibuat diagram Level Zero, berisi penguraian dari proses sistem yang ada di context diagram sebelumnya. Sistem ini memiliki 6 sub-proses, yaitu login, pendaftaran pasien, pendataan rekam medis, pencatatan persediaan obat, laporan, dan pengaturan khusus admin. Pada proses login, semua entitas kecuali pasien memberikan input username dan passwordnya lalu dicocokkan dengan data pada tabel login pada database klinik. Jika input yang dimasukkan cocok, maka entitas yang melakukan login dalam melakukan proses lain.

Proses pendaftaran pasien, dilakukan oleh pasien, suster dan administrator. Sistem akan memberikan jadwal dokter, kemudian pasien melakukan input pendaftaran. Data akan disimpan ke 
database. Sistem kemudian akan mengirim kembali urutan pendaftaran pasien ke pasien. Administrator melakukan proses, jika pasien langsung datang ke balai pengobatan. Proses pendataan rekam medis dilakukan oleh dokter dan administrator. Dokter atau administrator memasukkan input data rekam medis yang nantinya akan disimpan dalam database, kemudian sistem memberikan data rekam medis ke dokter dan administrator.

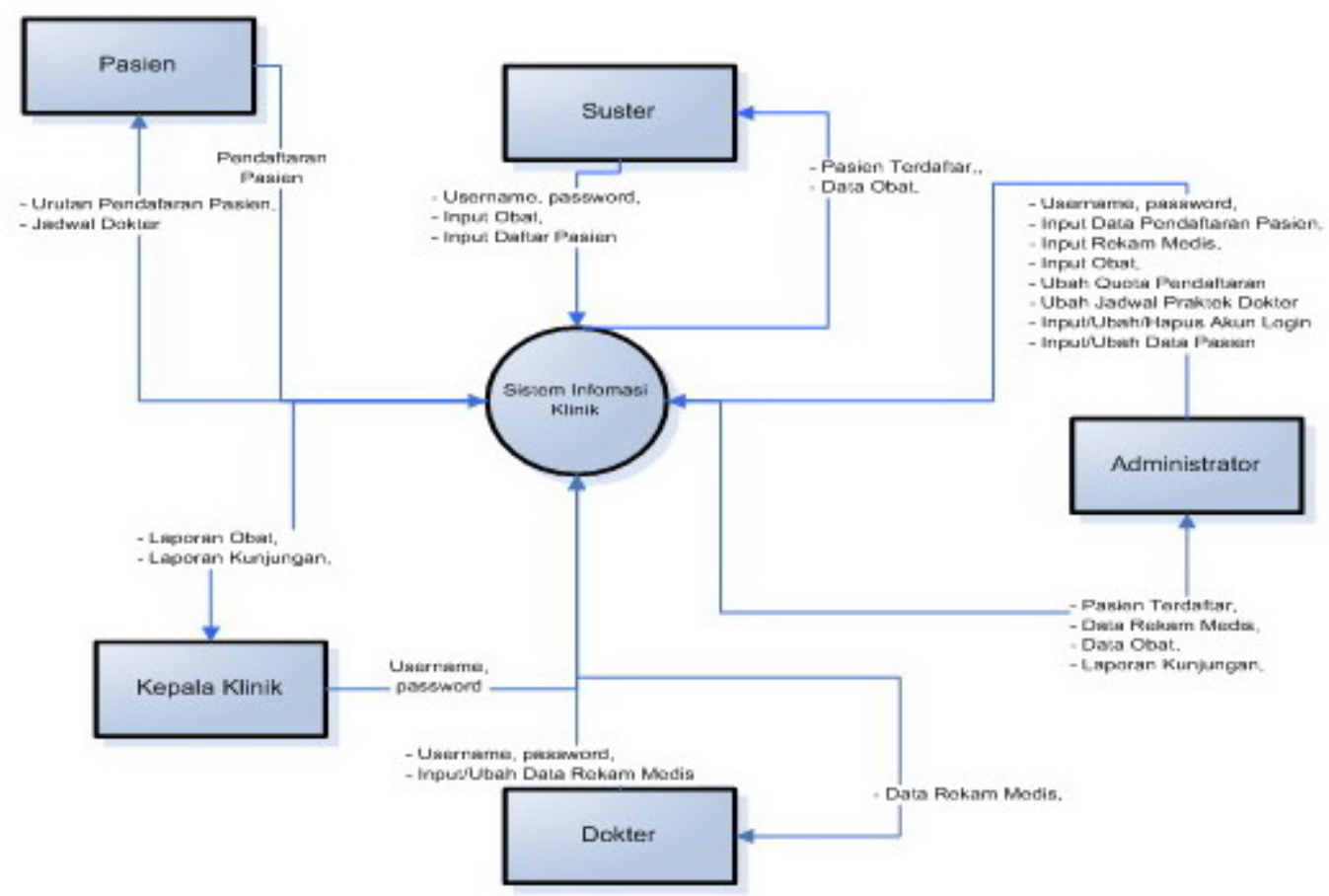

Gambar 3 Prosedur Berobat ke Dokter Umum

Pencatatan persediaan obat, dilakukan oleh suster. Administrator memasukkan input data obat yang masuk atau keluar kemudian disimpan di database. Proses laporan, berhubungan dengan entitas suster, kepala klinik, dan dokter. Sistem memberikan laporan kunjungan pasien harian, bulanan dan tahunan kepada dokter dan administrator, sedangkan laporan obat diberikan kepada suster dan administrator. Proses pengaturan khusus admin merupakan hak akses khusus administrator. Administrator dapat mengubah kuota pendaftaran, data pasien, akun login dan jadwal dokter.

\section{Perancangan Data}

Sistem informasi klinik memiliki satu database bernama database klinik yang digunakan untuk menyimpan data-data klinik. Gambar 4 Menunjukkan hubungan antar entitas pada database klinik. Database ini terdiri tabel, yaitu entitas login untuk menyimpan data pegawai klinik; pasien: entitas yang menyimpan data pegawai Kementerian Pertanian (KemTan) yang menjadi pasien; entitas tanggungan: entitas yang menyimpan data tanggungan pegawai Kementerian Pertanian; entitas pendaftaran pasien: entitas yang menyimpan data pendaftaran pasien setiap harinya; entitas periksa: entitas yang menyimpan data rekam medis pasien; entitas dokter: entitas berisi data-data dokter di balai pengobatan; entitas suster: entitas berisi data suster di balai pengobatan; entitas obat: entitas berisi data jenis-jenis obat di balai pengobatan; dan entitas transaksi obat: entitas berisi data transaksi obat di balai pengobatan. Model data aplikasi dapat dilihat pada Gambar 3, Entity Relationship Diagram. 

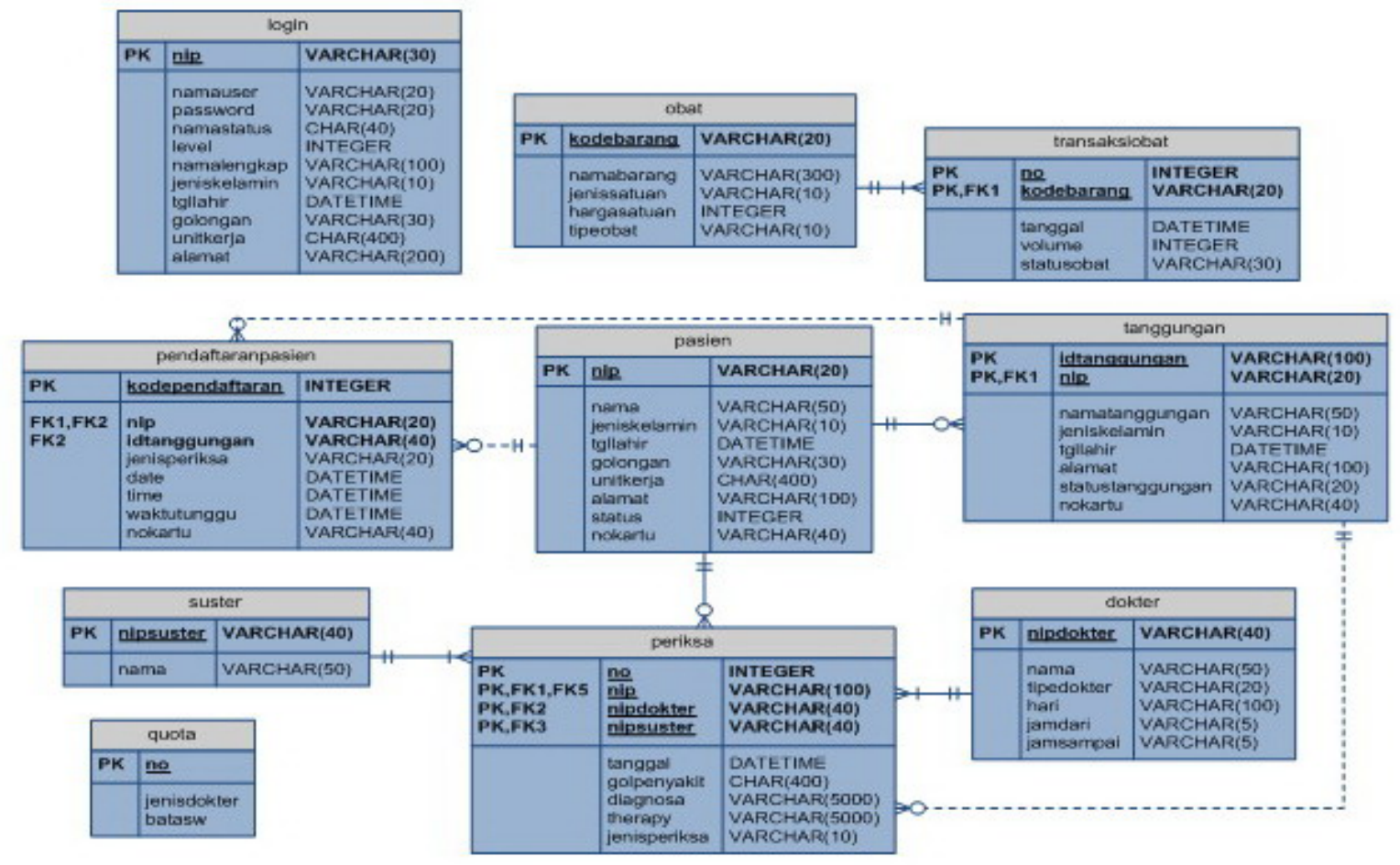

Gambar 4 Entity Relationship Diagram

\section{Implementasi Aplikasi Administrasi Layanan Pengobatan}

\section{Diagram Navigasi}

Diagram navigasi menggambarkan secara konseptual cara menjalankan aplikasi e-Klinik, mulai dari seorang pengguna, yaitu calon pasien yang akan mendaftarkan diri untuk berobat, prosesproses yang dilakukan oleh petugas, perawat dan dokter dalam menangani pasien itu. Apabila seluruh proses telah dilakukan, data kegiatan pengobatan pasien akan dicatat ke dalam database Klinik, termasuk di dalamnya, riwayat medis pasien tersebut. Selanjtnya secara berkala dapat dihasilkan laporan medikal yang berguna untuk manajemen. Navigasi dalam aplikasi sistem ini terdiri atas beberapa tahap, yaitu login, pendaftaran pasien, pendataan rekam medis, persediaan obat, dan pelaporan. Gambar 5 menjelaskan diagram navigasi tersebut.

\section{Pemeliharaan Database}

Sistem informasi klinik menggunakan MySQL. Database ini memiliki beberapa kelebihan karena dapat digunakan diberbagai platform sistem operasi, open source, dan memiliki interface terhadap berbagai aplikasi dan bahasa pemrograman. Database untuk aplikasi ini, diberi nama "klinik". Perancangan database dalam aplikasi ini digunakan 9 tabel, yaitu tabel "pasien", tabel "tanggungan”, tabel "pendaftaranpasien”, tabel "periksa”, tabel "login”, tabel “dokter”, tabel "suster”, tabel "obat", tabel "transaksiobat", tabel "kuota". Untuk pengelolaan database digunakan phpmyAdmin, dengan perangkat lunak WAMP. 


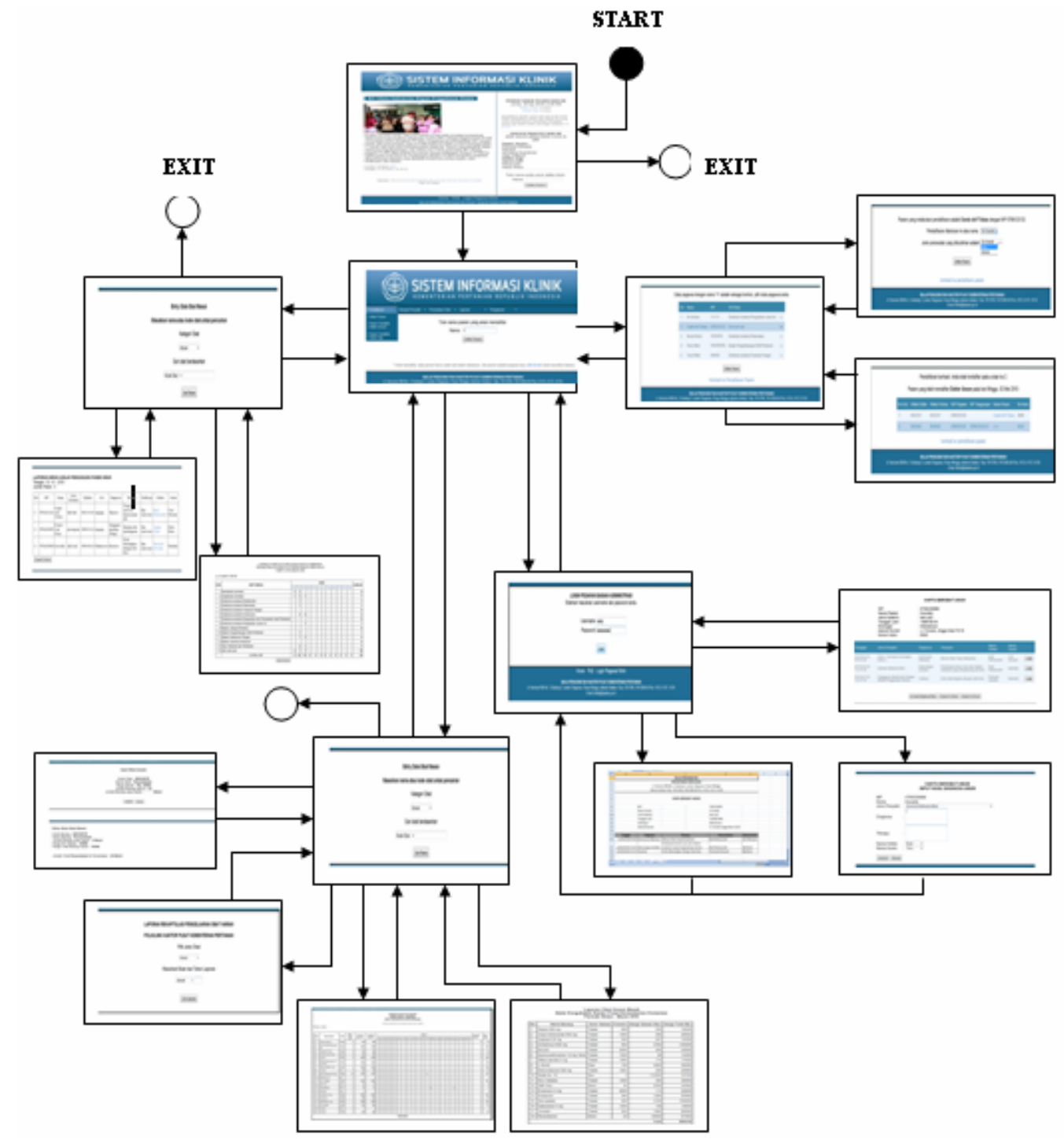

Gambar 5 Diagram Navigasi Aplikasi e-Klinik

\section{Tampilan Layar}

Desain tampilan aplikasi sistem informasi klinik ini dibuat menggunakan tools adobe dreamweaver CS3. Desain juga menampilkan halaman utama dan halaman depan dengan hak akses administrator saja, karena mewakili semua proses yang ada. Gambar 6 berikut ini adalah tampilan halaman utama.

\section{Halaman Utama dan Pendaftaran Pasien}

Di halaman utama Sistem Informasi Klinik, pasien dapat melihat jadwal dokter praktek, jumlah pasien yang telah mendaftar beserta urutannya. Pasien dapat mendaftarkan dirinya pada kotak di sebelah kanan bawah. Sementara itu, untuk administrator pendaftaran dapat dilakukan setelah login. 

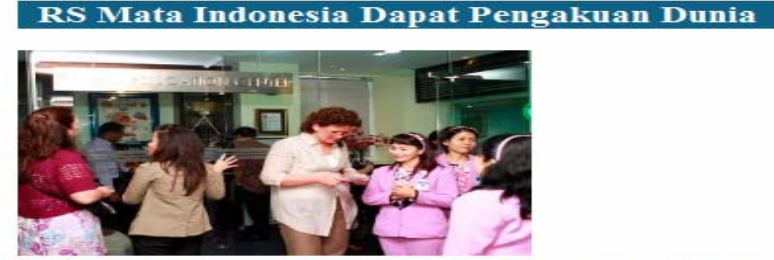
Kualitas layanan rumah sakit mata Indonesia kini telah mendapat pengakuan Association of Eye Hospitals (WAEH). Pengaluan ini menempatkan JEC sebagai rumah sakit mata pertama yang mewakili Indonesia dalam asosiasi beranggotakan 11 rumah sakit mata dari berbagai penjuru dunia itu. Seperti yang diungkap dalam siaran pers kepada Kompas.com, Selasa (30/3/2010), peresmian JEC sebagai anggota WAFH dilaksanakan bersamaan dengan kunjungan delegasi WAEH ke Jakarta pada awal Maret ini. Kedatangan delegasi WAEH merupakan rangkaian Mertene dan Jalar yang diad

sumber: Kompas (link)
tanggal: $31-03-2010,15: 16: 13$

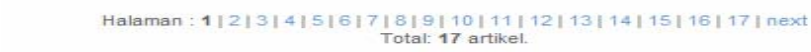

Home I FAQ | Login Pegawai Klinik

BALAI PENGOBATAN KANTOR PUSAT KEMENTERIAN PERTANIAN

J1. Harsono RM No. 3 Gedung C Lantai I Ragunan, Pasar Minggu Jakarta Selatan. Telp. 7815786, 7815380-84 Pes. 4135, 4137, 4139.

Gambar 6 Halaman Utama e-Klinik Kementerian Pertanian

Setelah memasukkan kata kunci nama pegawai yang ingin dicari, sistem akan mencari nama yang mendekati kata kunci yang dimasukkan tadi. Kemudian sistem akan memberikan tampilan daftar calon pasien yang telah mendaftar sebelumnya Jika memilih pegawai, maka pilihannya diri sendiri. Tetapi jika tanggungannya, maka pilih nama tanggungan yang tertera.

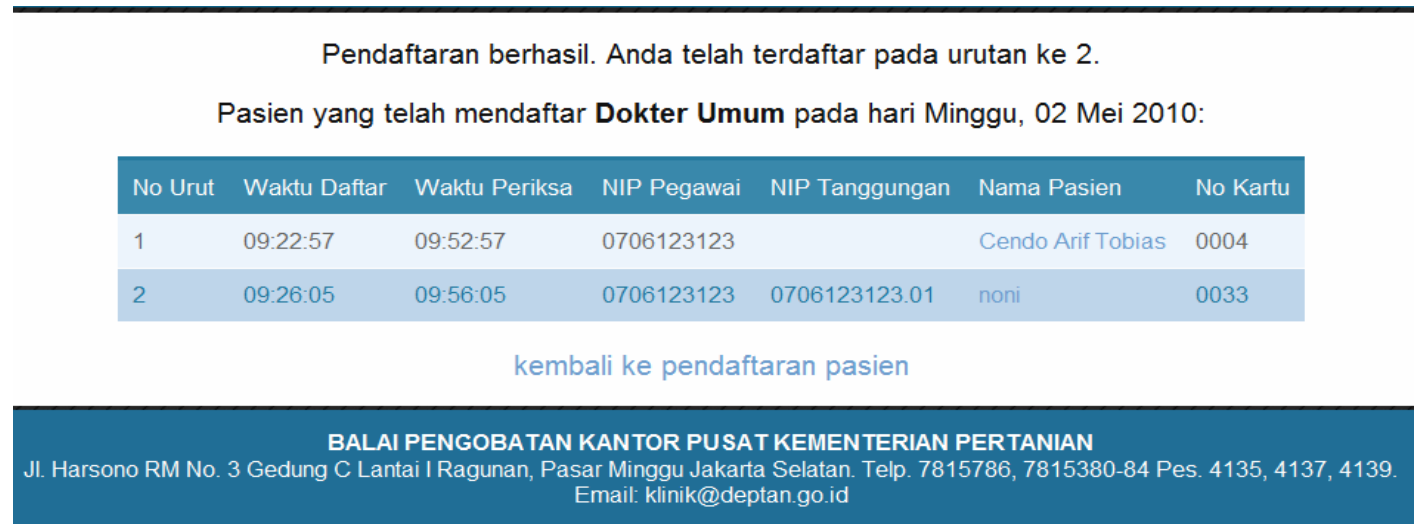

Gambar 7 Urutan Pendaftaran Pasien melalui e-Klinik Kementerian Pertanian

Jika pendaftaran berhasil, maka akan ditampilkan daftar pasien dan nomor kartunya seperti terlihat pada Gambar 7. Pada nomor urut kedua, terlihat nama yang baru saja mendaftar dan juga nama-nama selanjutnya, yaitu tanggungannya . 


\section{Pendataan Rekam Medis}

Pendataan rekam medis memiliki sistem pencarian yang kurang lebih sama dengan proses pendaftaran pasien. Diawali dengan mencari nama pasien yang akan diperiksa, dokter atau administrator dapat melakukan input data rekam medis seperti NIP, nama, jenis penyakit, hasil diagnosis, terapi, dan nama dokternya.

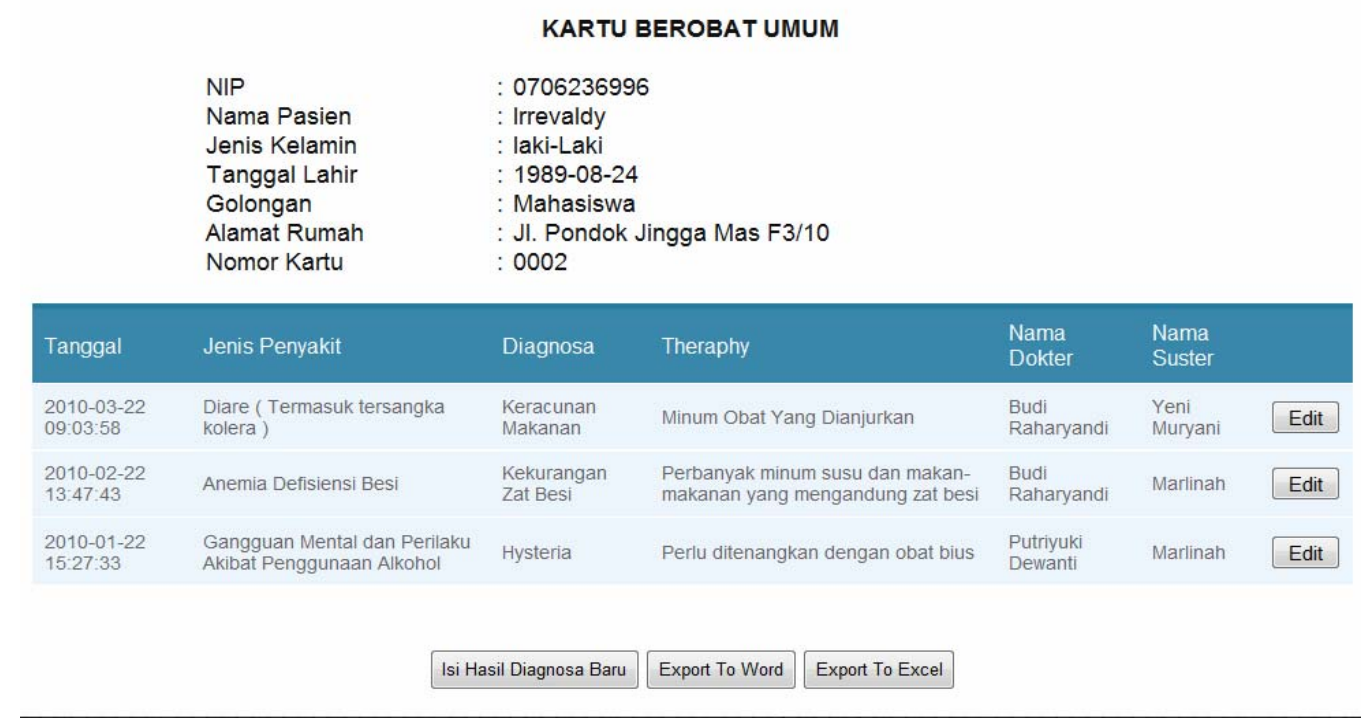

Gambar 8 Tampilan Data Rekam Medis e-Klinik Kementerian Pertanian

Setelah melakukan input data rekam medis, maka tampilan yang muncul adalah seperti pada Gambar 8. Di sini juga disediakan fitur edit data pasien dan export data ke word atau excel. Berikut ini tampilan dalam bentuk excel.

\section{Persediaan Obat}

Pada proses persediaan obat, entry data dilakukan untuk mengetahui jumlah obat yang masuk atau terpakai. Pencatatan dilakukan sore hari. Pencarian obat dilakukan dengan memasukkan kode obat atau nama obat. Setelah obat ditemukan, maka user memasukkan jumlah obat sesuai dengan jumlah yang masuk. Sistem akan mengolah data dan menampilkan jumlah barang yang masuk beserta jumlah total persediaan saat itu. Proses yang sama juga berlaku ketika obat keluar.

Berdasarkan data pemasukan obat belum dapat diperlihatkan arus obat masuk dan keluarnya, untuk itu dibuatlah laporan obat masuk, laporan obat keluar dan laporan rekapitulasi obat. Laporan obat masuk dan laporan obat keluar pada dasarnya sama, yaitu menampilkan obat apa saja yang masuk dan keluar setiap bulannya. Sedangkan laporan rekapitulasi obat menampilkan pergerakan obat masuk dan keluarnya sehingga terlihat dengan jelas berapa obat yang keluar setiap harinya. Prosesnya dimulai dengan memasukkan jenis laporan dan periode tahun atau bulan dari laporan. Berikut akan ditampilkan contoh laporan obat tersebut.

Pada gambar 9 terlihat jelas mengenai keluar-masuknya obat, termasuk pengeluaran hariannya sehingga memudahkan kepala klinik untuk mengetahui jumlah obat yang tersedia di balai pengobatan hingga saat ini. 


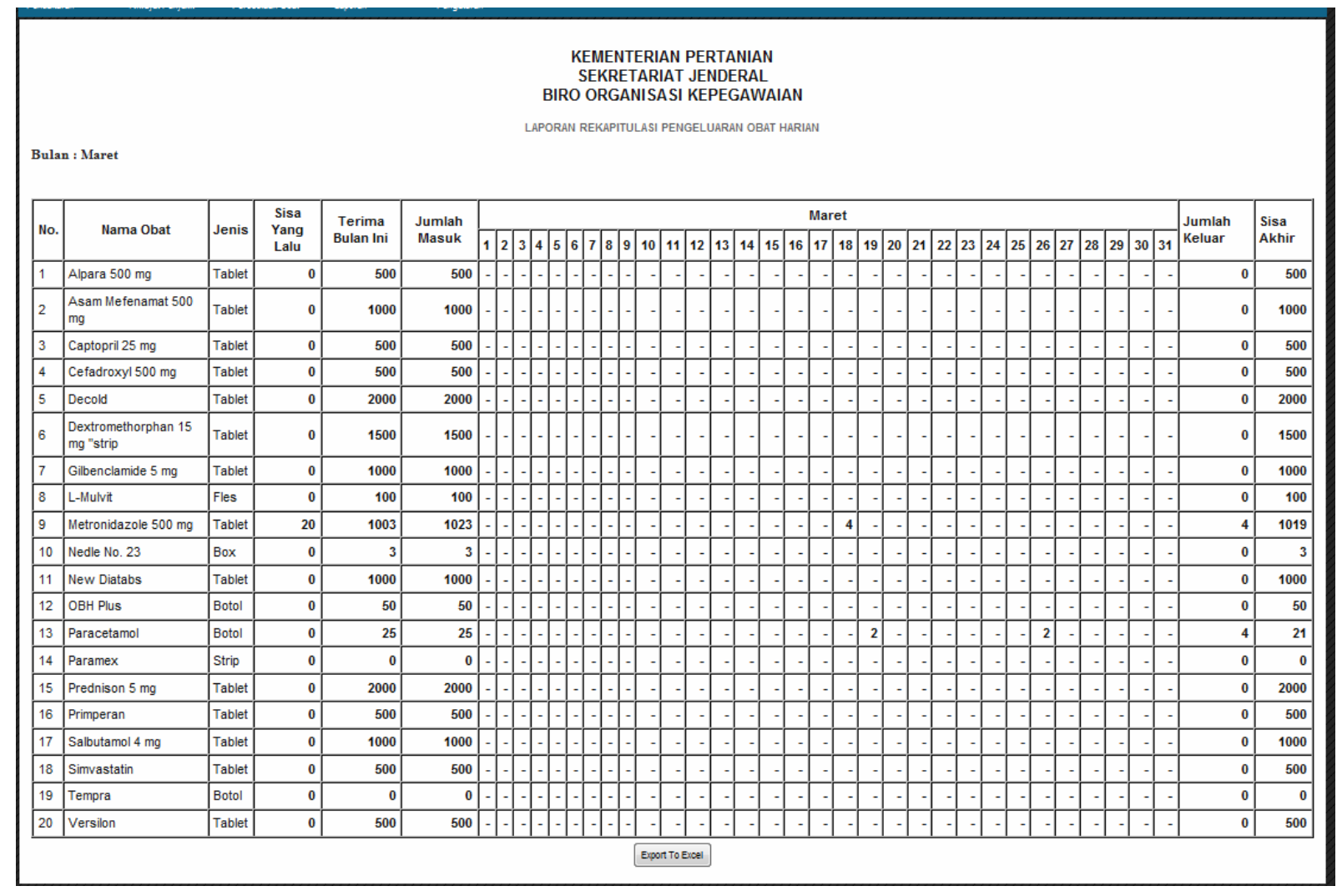

Gambar 9 Laporan Rekapitulasi Obat

\section{Laporan}

Pada sub-sistem laporan, ada berbagai macam jenis laporan, yaitu berdasarkan jenis periksa (harian, bulanan, tahunan), berdasarkan dokter, dan berdasarkan jenis penyakit.

\begin{tabular}{|c|c|c|c|c|c|c|c|c|c|c|}
\hline No & NIP & Nama & $\begin{array}{c}\text { Jenis } \\
\text { Kelamin }\end{array}$ & Tgllahir & Gol & Diagnosis & Therapy & UnitKerja & Dokter & Suster \\
\hline 1 & 0706123123 & $\begin{array}{l}\text { Cendo } \\
\text { Arif } \\
\text { Tobias }\end{array}$ & laki-laki & 1901-01-01 & magang & Depresi & $\begin{array}{l}\text { Terapi } \\
\text { motivasi } \\
\text { kepercayaan } \\
\text { diri }\end{array}$ & $\begin{array}{l}\text { Dan } \\
\text { Lain-Lain }\end{array}$ & $\begin{array}{l}\text { Budi } \\
\text { Raharyandi }\end{array}$ & $\begin{array}{l}\text { Yeni } \\
\text { Muryani }\end{array}$ \\
\hline 2 & 0706236895 & $\begin{array}{l}\text { Evania } \\
\text { Lina } \\
\text { Fasya }\end{array}$ & perempuan & $1989-10-23$ & magang & $\begin{array}{l}\text { Gangguan } \\
\text { gendang } \\
\text { telinga }\end{array}$ & $\begin{array}{l}\text { Bantuan alat } \\
\text { pendengaran }\end{array}$ & $\begin{array}{l}\text { Dan } \\
\text { Lain-Lain }\end{array}$ & $\begin{array}{l}\text { Agung } \\
\text { Cipta }\end{array}$ & $\begin{array}{l}\text { Mara } \\
\text { Dona }\end{array}$ \\
\hline 3 & 0706236996 & Irrevaldy & laki-Laki & 1989-08-24 & Mahasiswa & Hysteria & $\begin{array}{l}\text { Perlu } \\
\text { ditenangkan } \\
\text { dengan obat } \\
\text { bius }\end{array}$ & $\begin{array}{l}\text { Dan } \\
\text { Lain-Lain }\end{array}$ & $\begin{array}{l}\text { Putriyuki } \\
\text { Dewanti }\end{array}$ & Marlinah \\
\hline
\end{tabular}

Gambar 10 Laporan Kunjungan Pasien Harian 
Pada laporan kunjungan pasien harian seperti yang ditunjukkan pada Gambar 10, menunjukkan pasien yang melakukan kunjungan berobat pada hari tertentu sehingga mempermudah kepala klinik untuk mengetahui siapa saja yang datang berobat pada hari itu.

\section{Desain Pengaturan Khusus Administrator Sistem}

Pengaturan khusus admin merupakan sub-sistem khusus yang hak aksesnya hanya untuk admin. Ada berbagai macam pengaturan, yaitu pengaturan kuota pendaftaran, jadwal dokter, dan akun pengguna. Berikut adalah contoh desain pengaturan kuota.

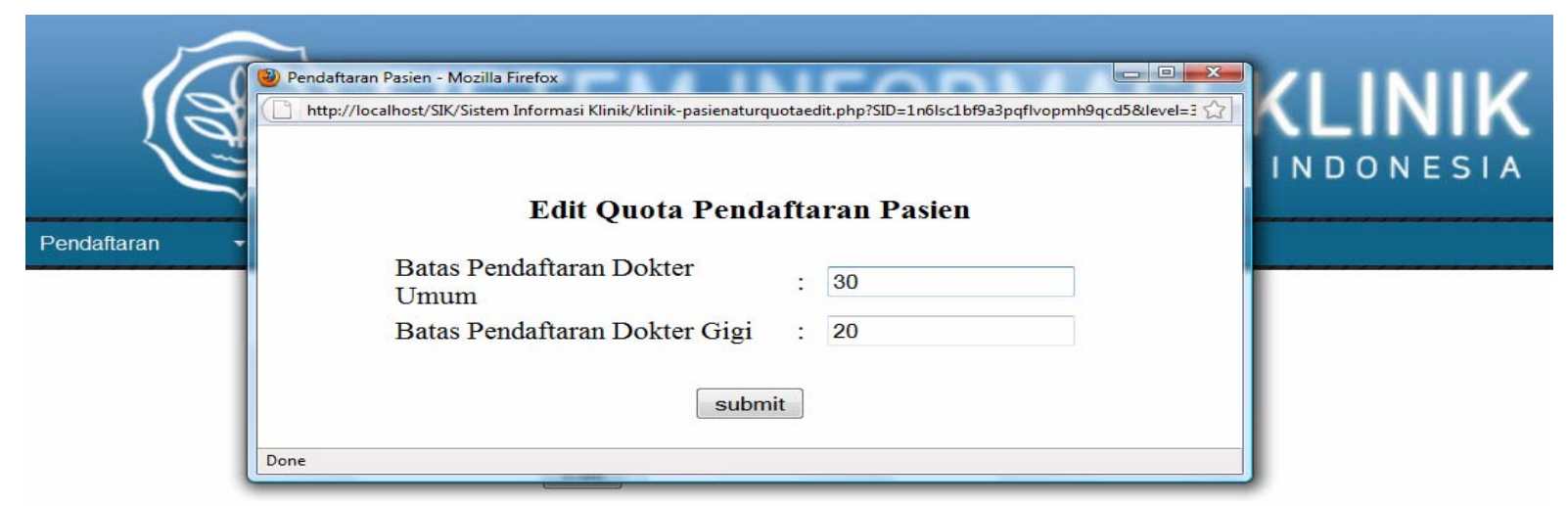

BALAI PENGOBATAN KANTOR PUSAT KEMENTERIAN PERTANIAN

J. Harsono RM No. 3 Gedung C Lantai I Ragunan, Pasar Minggu Jakarta Selatan. Telp. 7815786, 7815380-84 Pes. 4135, 4137, 4139. Email: klinik@deptan.go.id

Gambar 11 Edit Pengaturan Kuota Pasien

Salah satu pengaturan khusus admin adalah pengaturan kuota pasien. Ini diperlukan untuk membatasi jumlah pasien yang melakukan kunjungan berobat setiap harinya sesuai dengan prosedur balai pengobatan yang ada. Pada gambar 11 ditampilkan desain kuota pasien saat ini. Ketika di klik tombol edit, maka akan muncul child form sebagai pop-up gambar. Setelah batas pendaftaran yang baru di-submit, maka data kuota pendaftaran akan diolah yang mengubah data pada tabel kuota di database. Kemudian akan menampilkan konfirmasi batas pendaftaran kuota pasien yang telah terupdate.

\section{SIMPULAN}

Sistem informasi klinik berbasis web yang dibangun memudahkan layanan administrasi balai pengobatan yang sebelumnya masih manual. Walaupun layanan balai pengobatan sebelumnya menggunakan sistem manual sudah baik, namun tetap terjadi kendala dalam hal pendaftaran pasien, pencatatan rekam medis dan pelaporan. Sistem ini memberi manfaat karena data akan lebih aman, bisa diakses dari berbagai tempat sehingga memperkecil kemungkinan hilangnya data dan memperlancar prosedur yang pada balai pengobatan Kantor Pusat Pertanian. 


\section{DAFTAR PUSTAKA}

Budiono, M A. (2005). Kamus lengkap bahasa indonesia, Surabaya: Karya Agung.

Kirschman, C. F., and Fadel G. M. Classifying functions for mechanical design, Journal of Mechanical Design, 1998, 120 (3): 475-482.

O’Brien, J., and Marakas, G. M. (2008). Management information systems, New York: McGrawHill/Irwin.

Terninko J. Su-Field analysis, TRIZ Journal, February 2000, Retrieved from http://www.trizjournal.com.

Whitten, J. L., and Bentley, L.D., (2007). System analysis and design for the global enterprise, New York: McGraw-Hill/Irwin. 